\title{
Idaho National Engineering and Environmental Laboratory Offsite Environmental Surveillance Program Report: Third Quarter 1999
}

Roy Evans

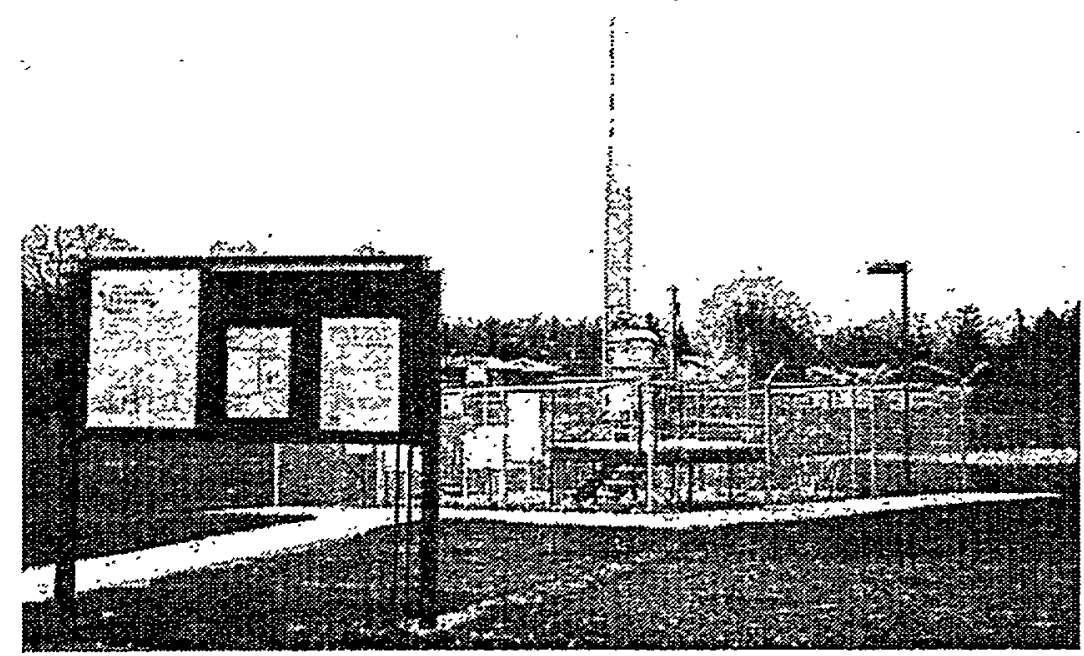

Community Monitoring Station at Mountain View Middle School Blackfoot

Environmental Science and Research Foundation, Inc. March 2000

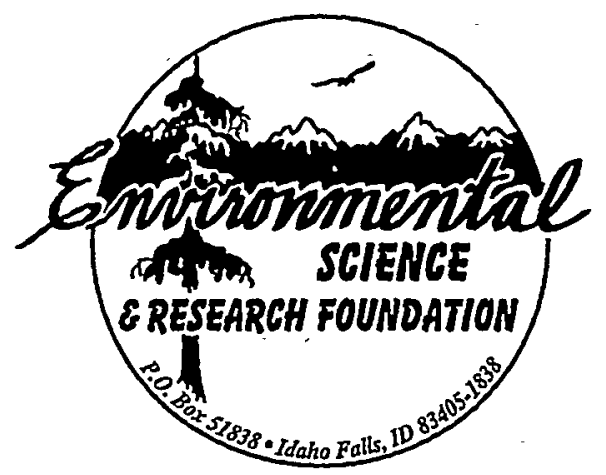


To increase public awareness and involvement in the INEEL offsite environmental surveillance program, the Foundation sponsors two Community Monitoring Stations, located at Mountain View Middle School in Blackfoot and Madison Middle School in Rexburg. Science teachers at the two schools manage the stations, collect the data, and use the data in their classrooms. The stations house equipment to monitor radioactivity and particulates (dust) in the air, environmental radiation levels, and weather conditions. The equipment provides real-time data for some measurements, such as weather conditions and gamma-radiation levels. For other types of measurements the equipment takes samples that are collected by the station managers and sent to laboratories for analysis. Current weather conditions and gamma radiation levels are displayed at each station, along with postings of laboratory results. The public is encouraged to visit the stations often to view-the equipment and check the data. 


\title{
RECERED \\ Idaho National Engineering and DEC 272000 Environmental Laboratory Offsite OSJI Environmental Surveillance Program Report: Third Quarter 1999
}

\author{
Roy Evans
}

Environmental Science and Research Foundation, Inc. Doyle Markham, Executive Director

March 2000

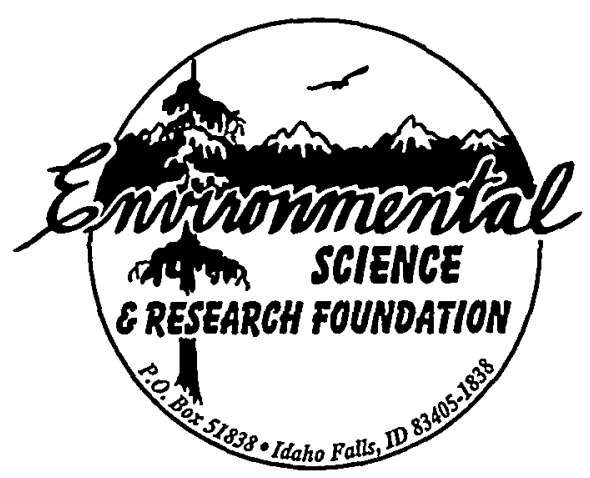

Program conducted for the U.S. Department of Energy, Idaho Operations Office Under Contract DE-AC07-94ID13268

Environmental Science and Research Foundation, Inc.

101 S. Park Avenue, Suite 2

P.O. Box 51838

Idaho Falls, Idaho 83405-1838 


\section{Executive Summary}

The Environmental Science and Research Foundation conducts an offsite environmental surveillance program for the Department of Energy's Idaho National Engineering and Environmental Laboratory (INEEL). The Foundation's environmental surveillance program monitors the effects, if any, of U.S. Department of Energy (DOE) activities on the offsite environment, collects data to confirm compliance with applicable environmental laws and regulations, and observes any trends in environmental levels of radioactivity. This report for the third quarter of 1999 is based on 704 samples of air, fine particulates, atmospheric moisture, precipitation, milk, and food. All concentrations of radioactivity found in these samples were consistent with concentrations which have been found in sampling during recent quarters and which have been attributed in the past to natural background radiation, worldwide fallout from past nuclear weapons testing, and nuclear operations around the world. No measured concentrations could be directly attributed to operations at the INEEL. Concentrations in all samples were below the guidelines set by both the DOE and the U.S. Environmental Protection Agency (EPA) for public protection.

\section{Program Description}

The Foundation collected filters weekly from low-volume air samplers at 12 offsite locations. Five were at distant locations and seven were near the INEEL boundary. An additional three air samplers were operated on the INEEL. Replicate samplers were operated at two offsite boundary locations for quality assurance purposes. Weekly measurements were made of gross alpha and gross beta activity in airborne particulates. Charcoal cartridges were screened weekly for the presence of iodine-131. At the end of the quarter, weekly filters from each location were combined to form a composite sample for that location. These composites were then analyzed for gamma-emitting radionuclides. Selected composites were also submitted for analyses for strontium-90 and transuranics (plutonium-238, plutonium-239/240, and americium-241).

$\mathrm{PM}_{10}$ samplers were operated at three offsite locations to sample airborne particulates with an aerodynamic diameter smaller than 10 microns. Particles this size can penetrate the body's natural air filtering system and enter the lungs. Atmospheric moisture and precipitation samples were collected to monitor for tritium. Atmospheric moisture samples were collected by sampling continuously for 13 weeks at each of four locations. The Foundation collected monthly precipitation samples at one onsite location and one offsite location, as well as a weekly precipitation sample at a second onsite location.

The Foundation collected a weekly milk sample from a dairy in Idaho Falls and collected monthly milk samples from eight additional dairies around the INEEL. All milk samples were analyzed for iodine-131. Lettuce from private gardens was sampled and analyzed. Three pronghorn antelope and seven mule deer killed on INEEL roadways were sampled, and thyroid, liver and muscle tissues were submitted for gamma spectroscopy.

For more information concerning the contents of this report, contact the Foundation at (208) 525-7102, or visit the Foundation's web page (http://esrf.org). 


\section{DISCLAIMER}

This report was prepared as an account of work sponsored by an agency of the United States Government. Neither the United States Government nor any agency thereof, nor any of their employees, make any warranty, express or implied, or assumes any legal liability or responsibility for the accuracy, completeness, or usefulness of any information, apparatus, product, or process disclosed, or represents that its use would not infringe privately owned rights. Reference herein to any specific commercial product, process, or service by trade name, trademark, manufacturer, or otherwise does not necessarily constitute or imply its endorsement, recommendation, or favoring by the United States Government or any agency thereof. The views and opinions of authors expressed herein do not necessarily state or reflect those of the United States Government or any agency thereof. 


\section{DISCLAIMER}

Portions of this document may be illegible in electronic image products. Images are produced from the best available original document. 


\section{Summary of Third Quarter 1999 Results}

Gross alpha and gross beta activities in low-volume air samples were within the expected range of values for background radioactivity. No statistically significant differences were found between the quarterly means of gross alpha and gross beta activities observed in samples from the INEEL, boundary, and distant stations. Iodine-131 was not found in any air sample.

$\mathrm{PM}_{10}$ sampling for respirable particulates continued at three locations: Atomic City, Rexburg, and Mountain View Middle School in Blackfoot. Twenty-four-hour samples were collected once every six days throughout the third quarter. Observed concentrations at the three stations were all below the short-term EPA standard of $150 \mu \mathrm{g} / \mathrm{m}^{3}$ averaged over 24 hours. One atmospheric moisture sample from Rexburg contained detectable tritium at a low level consistent with natural production by cosmic ray bombardment in the upper atmosphere. No tritium was detected in precipitation samples.

No detectable concentrations of iodine-131 were reported in the 38 milk samples collected during the third quarter. Seven of eight lettuce samples contained small but detectable concentrations of strontium-90, consistent with levels seen in past sampling and attributable to worldwide fallout from atmospheric weapons testing. One pronghorn antelope and two mule deer exhibited trace detections of cesium-137 in muscle tissue samples. One pronghorn antelope and one of the mule deer also had small concentrations of cesium-137 in their livers. These concentrations were consistent with concentrations found in recent game animal samples and are probably attributable to worldwide fallout, although a contribution from INEEL activities cannot be ruled out. 


\section{Table of Contents}

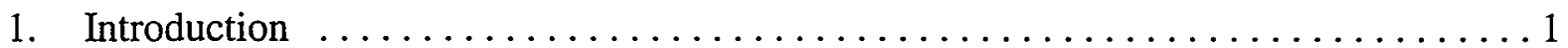

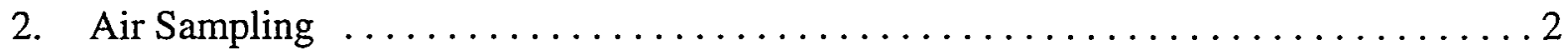

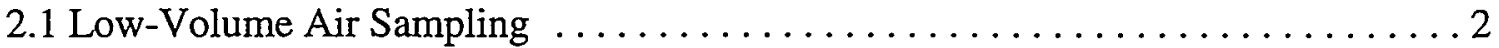

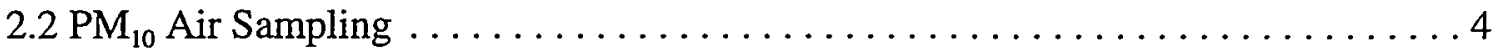

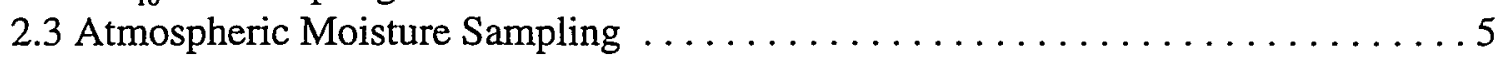

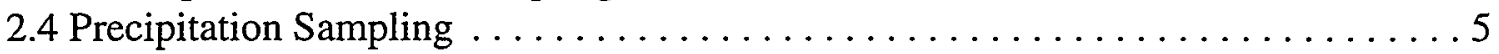

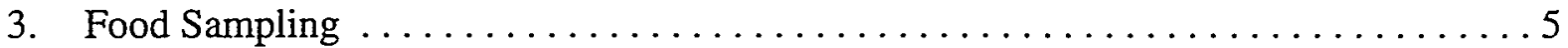

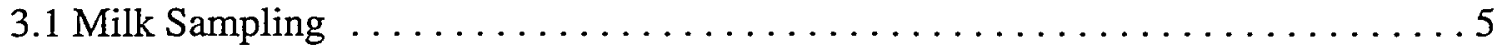

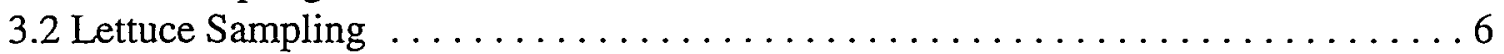

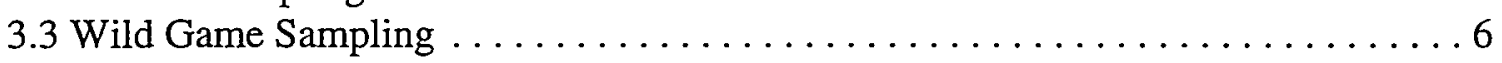

Appendix A: Summary of Environmental Surveillance Networks $\ldots \ldots \ldots \ldots \ldots \ldots 7$

Appendix B: Helpful Information for Readers $\ldots \ldots \ldots \ldots \ldots \ldots \ldots \ldots \ldots$

Appendix $\mathrm{C}$ : Weekly Gross Alpha and Beta Activities in Air $\ldots \ldots \ldots \ldots \ldots \ldots 1$

\section{Tables}

1. Gross Alpha Activity in Air . . . . . . . . . . . . . . . . . 3

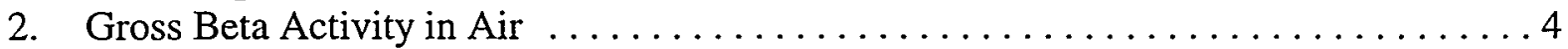

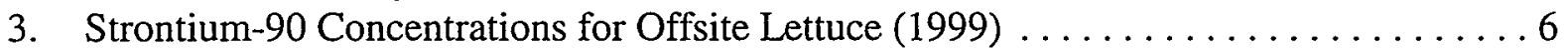

4. Cesium-137 Concentrations in Road-Killed Wild Game . . . . . . . . . . . . 6

A-1 Summary of the Foundation's Environmental Surveillance Program . . . . . . . 7

A-2 Approximate Minimum Detectable Concentrations for Radiological Analyses . . 8

\section{Figures}

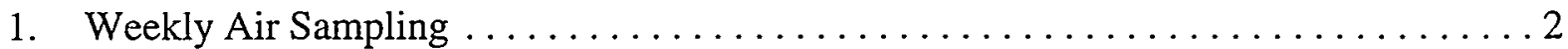

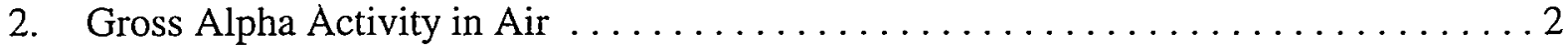

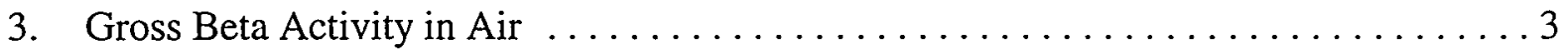

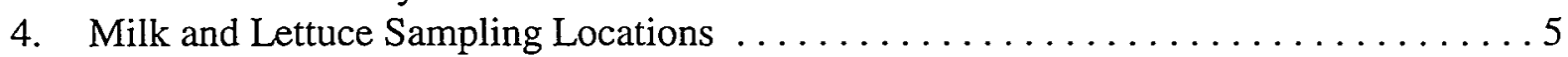




\section{Introduction}

This quarterly report summarizes the data collected by the Environmental Science and Research Foundation's offsite environmental surveillance program for the Department of Energy's Idaho National Engineering and Environmental Laboratory (INEEL) during the period July 1 to September 30, 1999. Consistent with requirements of applicable Department of Energy (DOE) Orders, the Foundation's environmental surveillance program monitors the effects, if any, of DOE activities on the offsite environment, collects data to verify compliance with applicable environmental laws and regulations, and observes trends in environmental levels of radioactivity. Appendix A summarizes the Foundation's surveillance program. Information useful in understanding this report is given in Appendix B.

Most of the reported environmental concentrations are at or near background levels of radioactivity; many results are near the detection limits of the laboratory procedures. Appendix A summarizes the approximate minimum detectable concentrations of radioactivity which can be detected and quantified for a given sample type and analysis. All results are reported with an associated 2s ("two sigma") uncertainty term. The Foundation uses the following method for interpreting analytical results near the minimum detectable concentration: results less than or equal to the $2 \mathrm{~s}$ uncertainty, which includes some negative values, are considered as "not detected." For results greater than $2 \mathrm{~s}$ (the 95 per cent confidence level), but not exceeding $3 \mathrm{~s}$ (the 99 per cent confidence interval), detection of the radioactivity is questionable. Results may exceed the $2 \mathrm{~s}$ level simply due to the inherent random nature of radioactive decay events. This is expected to occur approximately 2.5 per cent of the time. Results exceeding $3 \mathrm{~s}$ are interpreted as indicating the detection of radioactivity.

Where appropriate, measured airborne concentrations of radioactivity in this report are compared to the DOE derived concentration guides. The derived concentration guide is the concentration of a radionuclide which, under conditions of continuous exposure for a year, would result in an effective dose equivalent of 100 millirem (the DOE standard for members of the public). 


\section{Air Sampling}

\subsection{Low-Volume Air Sampling}

Airborne particulate radioactivity was continuously monitored by 17 air samplers (Figure 1), located to provide an effective network to detect INEEL releases of radioactivity. Five offsite air samplers are located at distant, or background, stations and seven are boundary stations, located near the INEEL. Three air samplers are situated on the INEEL. Two replicate samplers are also operated for quality control purposes. Onsite locations were used to make comparisons of airborne concentrations of radioactivity with boundary and distant locations. Each air sampler averaged a flow of approximately $50 \mathrm{~L} / \mathrm{min}$

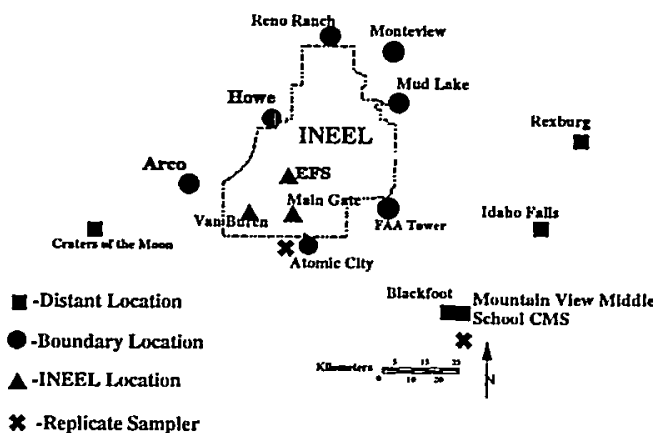

Figure 1 Weekly Air Sampling $\left(2 \mathrm{ft}^{3} / \mathrm{min}\right)$ through a filter head consisting of two types of filters -- a 1.2-micrometer pore size particulate filter and a charcoal cartridge for the monitoring of radioactive iodine. Filters on each sampler were changed weekly.

Various screening analyses were performed weekly. Charcoal cartridges were screened weekly in batches for ${ }^{131} \mathrm{I}$ activity. If activity was detected in any batch greater than a preset action level, cartridges were then analyzed individually. Particulate filters were counted each week for gross (nonspecific) beta activity in a low-background beta counter after waiting a minimum of four days for the naturally-occurring daughter products of radon and thoron to decay. The particulate filters were also counted for gross alpha activity. At the end of the quarter, weekly filters from each location were combined to form a composite. Composites were analyzed for ${ }^{137} \mathrm{Cs}$. Selected composites were also analyzed for ${ }^{90} \mathrm{Sr}$ or transuranic radionuclides $\left({ }^{238} \mathrm{Pu},{ }^{239 / 240} \mathrm{Pu}\right.$, and $\left.{ }^{241} \mathrm{Am}\right)$.

No ${ }^{131} \mathrm{I}$ was detected in any of the weekly charcoal cartridges during the third quarter.

Figure 2 shows the weekly gross alpha activities measured throughout the quarter. All measured gross alpha activities were within the expected range of background levels. Mean gross alpha activities measured on the INEEL were not significantly different from those measured at offsite locations. Table 1 summarizes the gross alpha measurements for the quarter.

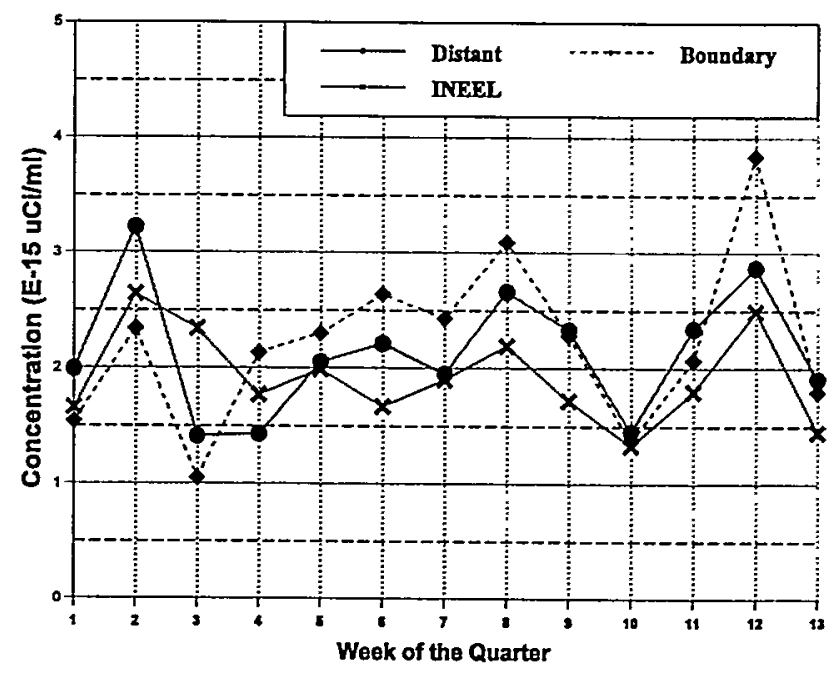

Figure 2 Gross Alpha Activity in Air 


\begin{tabular}{|c|c|c|c|c|}
\hline \multicolumn{5}{|c|}{$\begin{array}{c}\text { Table 1 } \\
\text { Gross Alpha Activity in Air } \\
\text { Third Quarter } 1999\end{array}$} \\
\hline \multirow[b]{2}{*}{ oup } & \multirow[b]{2}{*}{ Location } & \multirow[b]{2}{*}{$\begin{array}{l}\text { Number of } \\
\text { Samples } \\
\end{array}$} & \multicolumn{2}{|c|}{$\begin{array}{c}\text { Gross Alpha Concentration } \\
\left(\times 10^{* 5} \mathrm{\mu C} / \mathrm{ml}\right) \\
\end{array}$} \\
\hline & & & $\begin{array}{c}\text { Range of } \\
\text { Samples }\end{array}$ & Mean with $95 \%$ Confidence Interval \\
\hline \multirow{5}{*}{$\operatorname{tant}^{\text {Dis }}$} & \multirow[b]{2}{*}{ Blackfoot } & & & \\
\hline & & 13 & $1.2-4.3$ & $2.8 \pm 1.0$ \\
\hline & \multirow{3}{*}{$\begin{array}{l}\text { Craters of the Moon } \\
\text { Idaho Falls } \\
\text { Rexburg } \\
\text { Mountain View Middle } \\
\text { School (Replicate) }\end{array}$} & $\begin{array}{l}13 \\
13 \\
13\end{array}$ & $\begin{array}{l}0.4-3.4 \\
0.5-3.4 \\
0.3-2.8\end{array}$ & $\begin{array}{l}1.7 \pm 0.8 \\
2.2 \pm 1.1 \\
2.1 \pm 0.9\end{array}$ \\
\hline & & $13(13)$ & $1.4-3.1(0.9-4.0)$ & $2.2 \pm 0.8(2.2 \pm 1.0)$ \\
\hline & & & Group Mean & $2.2 \pm 1.0$ \\
\hline \multirow[t]{2}{*}{$\begin{array}{r}\text { B o } \\
\text { undary }\end{array}$} & Arco & 13 & $1.0-3.3$ & $1.9 \pm 0.9$ \\
\hline & $\begin{array}{l}\text { Atomic City (Replicate) } \\
\text { FAA Tower } \\
\text { Howe } \\
\text { Monteview } \\
\text { Mud Lake } \\
\text { Reno Ranch }\end{array}$ & $\begin{array}{c}13(12) \\
13 \\
13 \\
13 \\
13 \\
13\end{array}$ & $\begin{array}{c}1.2-4.1(1.2-3.0) \\
0.5-3.0 \\
1.2-8.7 \\
0.8-3.2 \\
1.3-3.6 \\
-0.7-3.0 \\
\text { Group Mean }\end{array}$ & $\begin{array}{c}2.1 \pm 0.9(1.9 \pm 1.0) \\
1.7 \pm 1.0 \\
3.2 \pm 1.8 \\
2.3 \pm 1.0 \\
2.4 \pm 0.9 \\
1.7 \pm 1.0 \\
2.2 \pm 1.1\end{array}$ \\
\hline \multirow[t]{3}{*}{ EEL } & \multirow{3}{*}{$\begin{array}{l}\text { EFS } \\
\text { Main Gate } \\
\text { Van Buren }\end{array}$} & 13 & $0.8-2.5$ & $1.8 \pm 1.0$ \\
\hline & & $\begin{array}{l}13 \\
13\end{array}$ & $\begin{array}{l}0.6-2.7 \\
1.2-3.3\end{array}$ & $\begin{array}{l}1.8 \pm 0.9 \\
2.2 \pm 1.1 \\
\end{array}$ \\
\hline & & & Group Mean & $1.9 \pm 1.0$ \\
\hline \multicolumn{5}{|c|}{ DOE Derived Concentration Guide 20} \\
\hline
\end{tabular}

Figure 3 shows gross beta activities over the 13-week quarter. All measured beta activities were also within the range of expected background values. Table 2 summarizes gross beta air activity measurements for the quarter. There was no statistically significant difference between the means of gross beta activities measured onsite and those measured offsite.

Replicate low volume samplers were operated for quality assurance purposes at Mountain View Middle School in Blackfoot and at Atomic City. T-tests were performed to detect differences between the samplers and their corresponding replicate sampler for both gross alpha and gross beta. At the 95 per cent confidence level, there were no significant

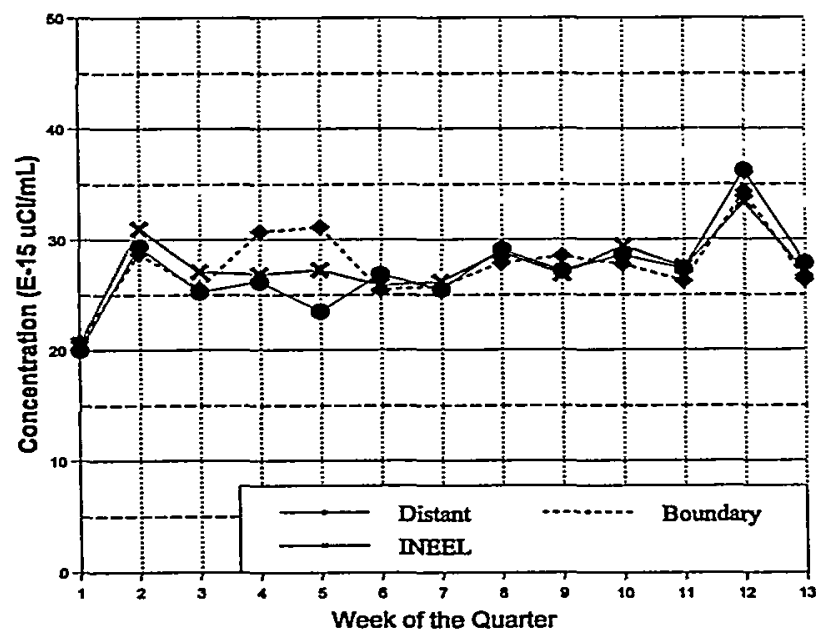

Figure 3 Gross Beta Activity in Air 
differences in replicate measurements of gross alpha or gross beta activity at either location. Appendix $\mathrm{C}$ contains the observed values of gross alpha and gross beta activities found in weekly air samples.

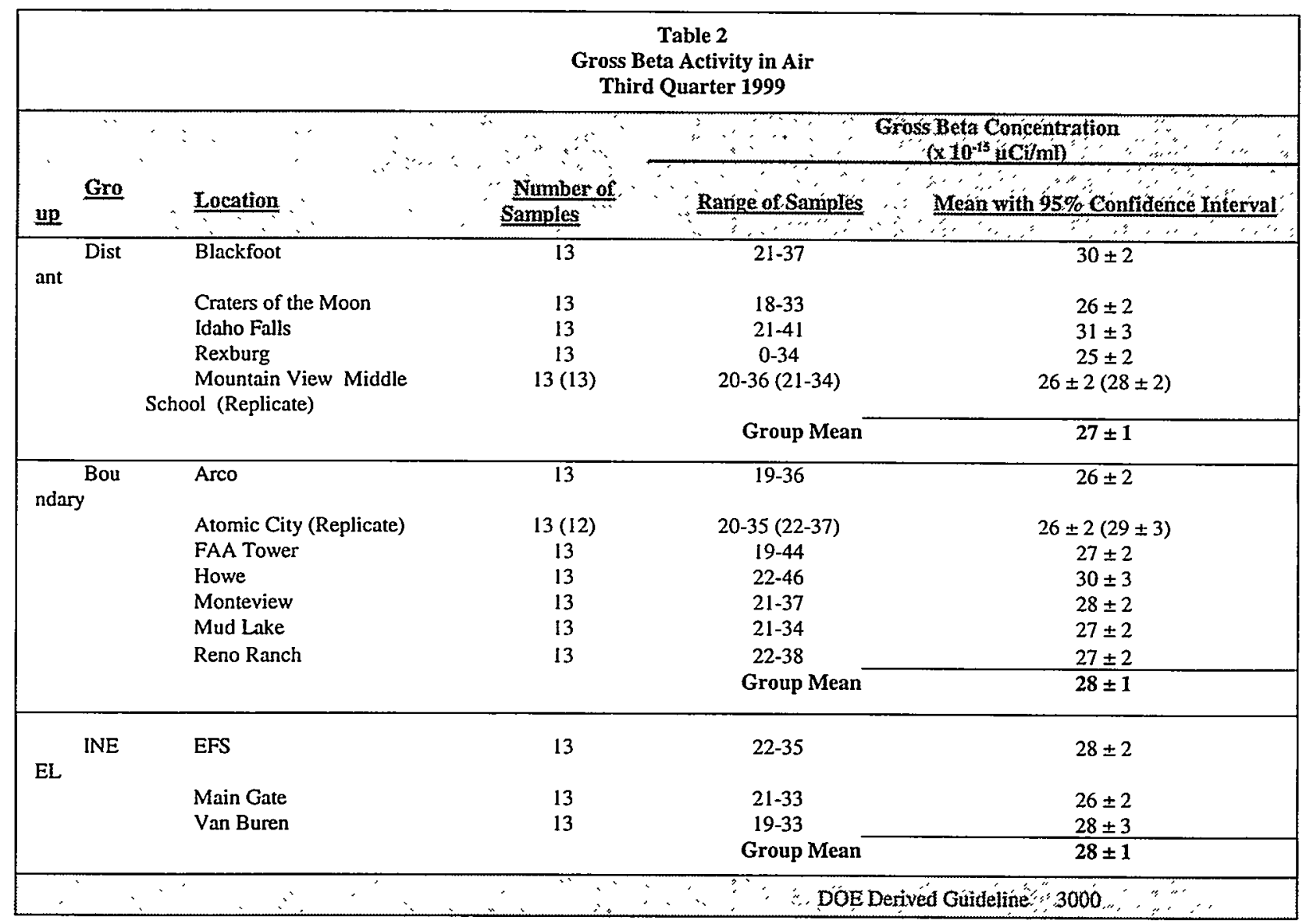

No samples exhibited concentrations of human-made gamma-emitting radionuclides. Selected quarterly composite samples were analyzed for transuranics of interest $\left({ }^{24 \mathrm{I}} \mathrm{Am},{ }^{238} \mathrm{Pu}\right.$, and ${ }^{239} 240 \mathrm{Pu}$ ). Americium-241 was reported as detectable in two samples. The composite sample from Arco was reported to contain ${ }^{241} \mathrm{Am}$ at a concentration of $(2.8 \pm 2.2) \times 10^{-18} \mu \mathrm{Ci} / \mathrm{mL}$, and the composite sample from the replicate sampler at Mountain View Middle School in Blackfoot was reported to contain ${ }^{241} \mathrm{Am}$ at a concentration of $(2.5 \pm 2.1) \times 10^{-18} \mu \mathrm{Ci} / \mathrm{ml}$. These reported concentrations are in the range of two to three sample standard deviations, and detection is therefore questionable. Several composite samples were also selected for ${ }^{90} \mathrm{Sr}$ analysis. Strontium-90 was reported as detectable in two samples; the composite sample from Madison Middle School in Rexburg was reported to contain $(7.6 \pm 5.7) \times 10^{-17} \mu \mathrm{Ci} / \mathrm{mL}$, and the sample from Mud Lake was reported to contain $(6.9 \pm 5.7) \times 10^{-17} \mu \mathrm{Ci} / \mathrm{ml}$ of ${ }^{90} \mathrm{Sr}$. These detections are also in the questionable range of two to three sample standard deviations. Whether or not the reported detections of ${ }^{241} \mathrm{Am}$ and ${ }^{90} \mathrm{Sr}$ represent real environmental concentrations, these values are far below the applicable derived concentration guides and present no threat to human health. 


\section{2 $\mathrm{PM}_{10}$ Air Sampling}

Air sampling for respirable particulates continued at Madison Middle School (Rexburg), Mountain View Middle School (Blackfoot), and Atomic City. $\mathrm{PM}_{10}$ samplers were used to sample airborne particulates with aerodynamic diameters smaller than 10 microns. Particles this size can penetrate the body's natural air filtering system and enter the lungs. These filters are not analyzed for radionuclides.

Samples were collected every sixth day from Rexburg, Blackfoot, and Atomic City. Concentrations at Rexburg ranged from 3 to $37 \mu \mathrm{g} / \mathrm{m}^{3}$, with an average of $20 \mu \mathrm{g} / \mathrm{m}^{3}$. At the Blackfoot location, values ranged from 7 to $64 \mu \mathrm{g} / \mathrm{m}^{3}$ with an average concentration of $25 \mu \mathrm{g} / \mathrm{m}^{3}$. In Atomic City the concentrations ranged from 7 to $42 \mu \mathrm{g} / \mathrm{m}^{3}$ with an average concentration of $23 \mu \mathrm{g} / \mathrm{m}^{3}$. The EPA standard is $150 \mu \mathrm{g} / \mathrm{m}^{3}$ averaged over 24 hours, and $50 \mu \mathrm{g} / \mathrm{m}^{3}$ averaged over the entire year.

\subsection{Atmospheric Moisture Sampling}

Four atmospheric moisture samples were obtained from Idaho Falls, Rexburg, Blackfoot and Atomic City during this reporting period. Samples were collected by passing air through a column of silica gel which absorbed water vapor. Tritium concentrations were determined by extracting water from the silica gel and counting the water sample by liquid scintillation. Only the sample from Rexburg contained detectable tritium at a concentration in air of $(5.8 \pm 5.6) \times 10^{-14}$ $\mu \mathrm{Ci} / \mathrm{ml}$. Tritium at this concentration is probably attributable to natural production by cosmic ray bombardment of the upper atmosphere.

\subsection{Precipitation Sampling}

Five precipitation samples were collected from Idaho Falls and onsite locations at the Central Facilities Area (CFA) and the Experimental Field Station (EFS) and analyzed for tritium. No tritium was detected at any location.

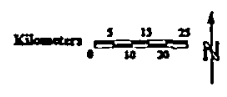

\section{Food Sampling}

\subsection{Milk Sampling}

Milk samples were collected weekly in Idaho Falls and monthly at eight other locations around the INEEL (Figure 4). Two types of locations were sampled: single family dairies and large commercial dairies. Each milk sample was analyzed for ${ }^{131} \mathrm{I}$

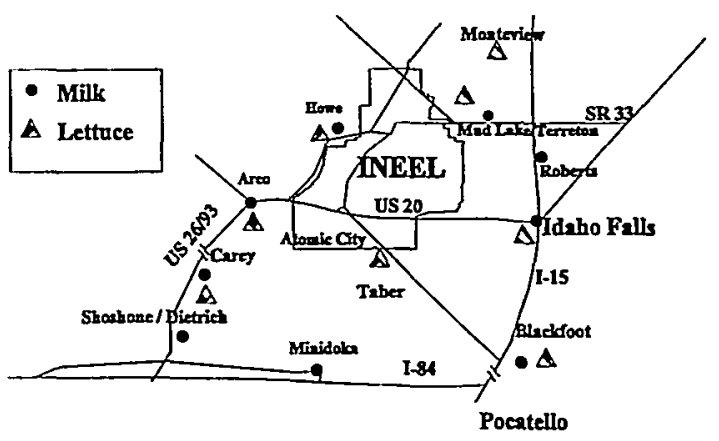

Figure 4 Milk and Lettuce Sampling Locations 
by gamma spectrometry. Results were decay-corrected to the time of sample collection. A total of 38 milk samples were collected during the third quarter. None of the samples exhibited detectable concentrations of ${ }^{131} \mathrm{I}$.

\subsection{Lettuce Sampling}

Eight lettuce samples were collected from private gardens and analyzed for strontium-90. Seven of the lettuce samples contained detectable amounts of strontium-90. Table 3 shows sample locations and concentrations. Activities found in the samples were consistent with concentrations observed near the INEEL in recent sampling, attributable to worldwide fallout from atmospheric weapons testing, and posed no threat to human or livestock health.

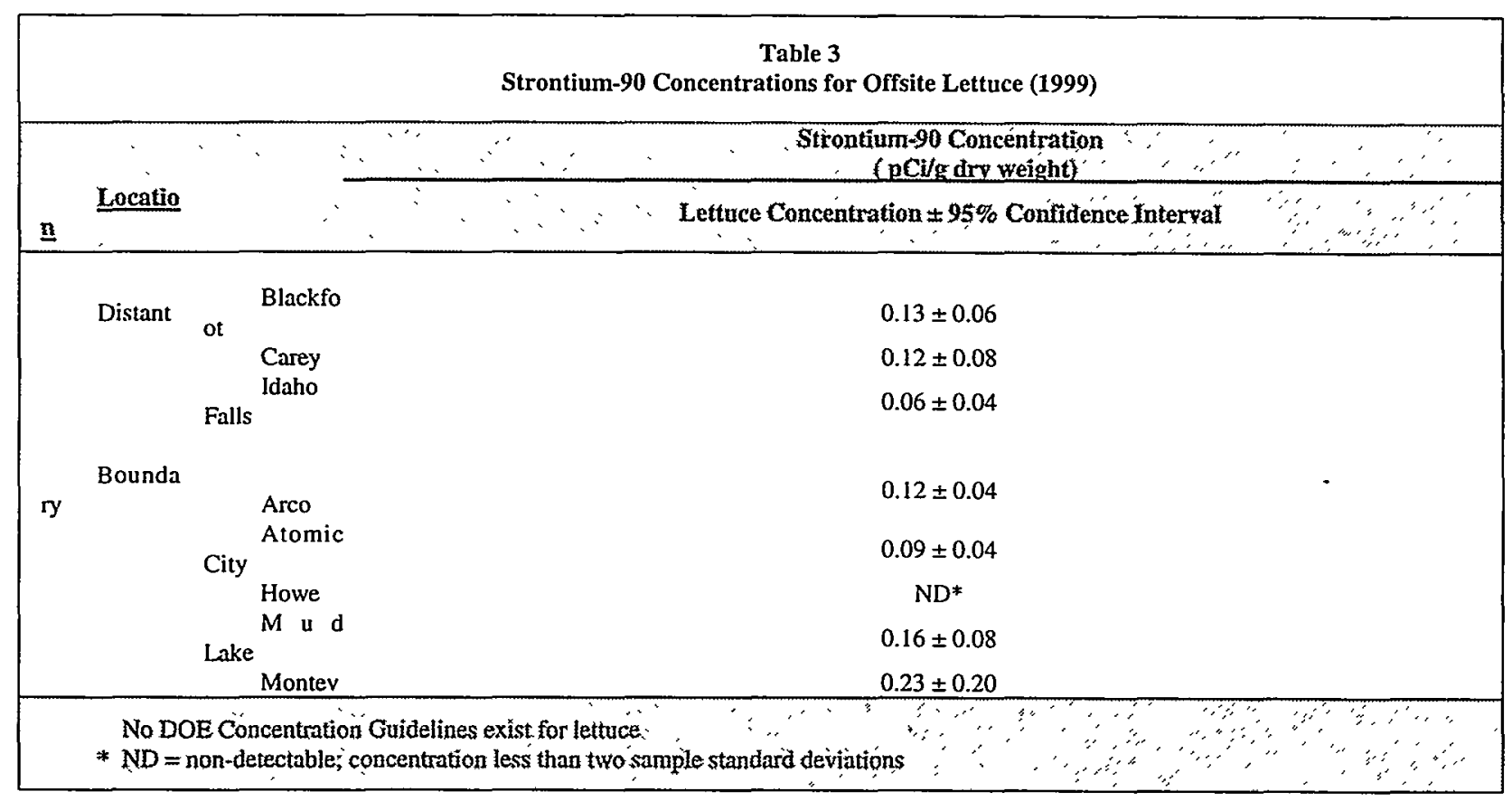

\subsection{Wild Game Sampling}

Three pronghorn antelope and seven mule deer killed accidently on INEEL roads were sampled during the third quarter of 1999. Liver, muscle and thyroid samples were collected and analyzed for cesium-137 by gamma spectroscopy. Muscle tissue from one pronghorn antelope and two mule deer exhibited detectable cesium-137 activities. Liver tissue samples from one pronghorn antelope and one mule deer also contained detectable cesium-137 activity. Table 4 summarizes these detections. All of these small activities are within the range of historical values and can be attributed to the ingestion of radionuclides from worldwide fallout from atmospheric nuclear weapons testing. 
3. Food Sampling

\begin{tabular}{|c|c|c|c|}
\hline \multicolumn{4}{|c|}{$\begin{array}{c}\text { Table } 4 \\
\text { Cesium-137 Concentrations in Road-Killed Wild Game } \\
\text { Third Quarter } 1999\end{array}$} \\
\hline Collection Date & Species & Tissure & $\begin{array}{c}\text { Cs-137 Concentration } \\
\left(\mu \mathrm{CV} / \mathrm{g} \times 10^{\circ} \pm 2 s\right)\end{array}$ \\
\hline $07 / 06 / 99$ & pronghorn & muscle & $3.9 \pm 2.7$ \\
\hline $07 / 06 / 99$ & pronghorn & liver & $6.5 \pm 5.0$ \\
\hline $07 / 26 / 99$ & mule deer & muscle & $9.5 \pm 3.2$ \\
\hline $09 / 21 / 99$ & mule deer & liver & $4.4 \pm 3.7$ \\
\hline $09 / 23 / 99$ & mule deer & muscle & $13.5 \pm 3.2$ \\
\hline
\end{tabular}




\section{Appendix A}

\section{Summary \\ of \\ Environmental Surveillance Networks}

\begin{tabular}{|c|c|c|c|c|}
\hline \multicolumn{5}{|c|}{$\begin{array}{l}\text { Table A-1 } \\
\text { Summary of the Foundation's Environmental Surveillance Program }\end{array}$} \\
\hline \multirow{2}{*}{$\begin{array}{r}\text { Sample Type } \\
\text { Analysis } \\
\end{array}$} & \multirow{2}{*}{$\begin{array}{l}\text { Collection } \\
\text { Frequency }\end{array}$} & \multicolumn{3}{|c|}{ Locations } \\
\hline & & Distant & Boundary & INEEL \\
\hline Air & & & & \\
\hline Gross Alpha & weekly & $\begin{array}{l}\text { Blackfoot(2), Craters of the Moon, Idaho } \\
\text { Falls, Rexburg }\end{array}$ & $\begin{array}{l}\text { Arco, Atomic City, FAA Tower, Howe, } \\
\text { Monteview, Mud Lake, Reno Ranch }\end{array}$ & $\begin{array}{l}\text { Main Gate, EFS, Van } \\
\text { Buren }\end{array}$ \\
\hline $\begin{array}{r}\text { Gross Beta } \\
1_{13} i_{1} \\
\end{array}$ & weekly & $\begin{array}{l}\text { Blackfoot(2), Craters of the Moon, Idaho } \\
\text { Falls, Rexburg }\end{array}$ & $\begin{array}{l}\text { Arco, Atomic City, FAA Tower, Howe, } \\
\text { Monteview, Mud Lake, Reno Ranch }\end{array}$ & $\begin{array}{l}\text { Main Gate, EFS, Van } \\
\text { Buren }\end{array}$ \\
\hline $\begin{array}{r}\text { Gamma Spec } \\
\text { Particulate Mass }\end{array}$ & quarterly & $\begin{array}{l}\text { Blackfoot(2), Craters of the Moon, Idaho } \\
\text { Falls, Rexburg }\end{array}$ & $\begin{array}{l}\text { Arco, Atomic City, FAA Tower, Howe, } \\
\text { Monteview, Mud Lake, Reno Ranch }\end{array}$ & $\begin{array}{l}\text { Main Gate, EFS, Van } \\
\text { Buren }\end{array}$ \\
\hline $\begin{array}{l}{ }^{s 0} \mathrm{Sr} \\
\text { Transuranics }\end{array}$ & quarterly & Rotating schedule & Rotating schedule & Rotating schedule \\
\hline $\mathrm{PM}-10$ & every sixth day & Rexburg, Blackfoot(2) & Atomic City & None \\
\hline \multicolumn{5}{|l|}{ Air Moisture } \\
\hline Tritium & 4 to 13 weeks & Idaho Falls & Atomic City & None \\
\hline \multicolumn{5}{|l|}{ Precipitation } \\
\hline Tritium & monthly & Idaho Falls & None & CFA \\
\hline Tritium & weekly & None & None & EFS \\
\hline \multicolumn{5}{|l|}{ Surface $\mathrm{H}_{2} \mathrm{O}$} \\
\hline $\begin{array}{r}\text { Gross Alpha, } \\
\text { Gross Beta, }{ }^{3} \mathrm{H} \\
\end{array}$ & semiannually & $\begin{array}{l}\text { Twin Falls, Buhl, Hagerman } \\
\text { Idaho Falls, Bliss }\end{array}$ & None & None \\
\hline \multicolumn{5}{|l|}{ Drinking $\mathrm{H}_{2} \mathrm{O}$} \\
\hline $\begin{array}{r}\text { Gross Alpha } \\
\text { Gross Beta }{ }_{3}{ }^{3} \mathrm{H}\end{array}$ & semiannually & $\begin{array}{l}\text { Aberdeen, Blackfoot, Carey, Idaho Falls, } \\
\text { Fort Hall, Minidoka, Roberts, Shoshone }\end{array}$ & $\begin{array}{l}\text { Arco, Atomic City, Howe, Monteview, } \\
\text { Mud Lake }\end{array}$ & None \\
\hline Milk & & 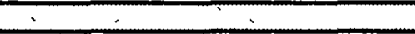 & - & $\overline{-}$ \\
\hline TiII & weekly & Idaho Falls & None & None \\
\hline$" n_{I}$ & monthly & $\begin{array}{l}\text { Blackfoot, Carey, Dietrich, Minidoka, } \\
\text { Roberts }\end{array}$ & Howe, Terreton, Arco & None \\
\hline${ }^{\substack{\text { Tritium } \\
{ }^{\infty} \mathrm{Sr}}}$ & annually & $\begin{array}{l}\text { Blackfoot, Carey, Dietrich, Idaho Falls, } \\
\text { Minidoka, Roberts }\end{array}$ & Howe, Terreton, Arco & None \\
\hline \multicolumn{5}{|l|}{ Potatoes } \\
\hline Gamma Spec & annually & Blackfoot, Idaho Falls, Rupert & Arco, Monteview, Taber & None \\
\hline \multicolumn{5}{|l|}{ Wheat } \\
\hline $\begin{array}{r}\text { Gamma Sper } \\
{ }_{{ }^{\circ 0} \mathrm{Sr}}\end{array}$ & annually & $\begin{array}{l}\text { Blackfoot, Dietrich, Idaho Falls, } \\
\text { Minidoka, Carey }\end{array}$ & $\begin{array}{l}\text { Arco, Monteview, Mud Lake, Taber, } \\
\text { Terreton }\end{array}$ & None \\
\hline \multicolumn{5}{|l|}{ Lettuce } \\
\hline $\begin{array}{r}\text { Gamma Spec } \\
{ }_{90}^{\infty} \mathrm{Sr}\end{array}$ & annually & $\begin{array}{l}\text { Blackfoot, Carey, Idaho Falls, Pocatello* } \\
\text { (* none available in 1999) }\end{array}$ & $\begin{array}{l}\text { Arco, Atomic City, Howe, Mud Lake, } \\
\text { Monteview }\end{array}$ & None \\
\hline \multicolumn{5}{|l|}{ Fish } \\
\hline Gamma Spec & annually & None & None & Big Lost River \\
\hline \multicolumn{5}{|l|}{ Sheep } \\
\hline Gamma Spec & annually & Blackfoot & None & INEEL grazing areas \\
\hline Waterfowl & & & & 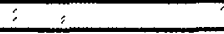 \\
\hline $\begin{array}{l}\text { Gamma Spec } \\
{ }^{9} \text { Sr Transuranics }\end{array}$ & annually & Fort Hall & None & Waste disposal ponds \\
\hline Game & & $\div$ & & \\
\hline Gamma Spec & varies & None & None & INEEL roads \\
\hline Soil & & $\because$ & & \\
\hline $\begin{array}{l}\text { Gamma Spec } \\
{ }_{{ }^{0} \mathrm{Sr}} \\
\text { Transuranics }\end{array}$ & biennially & $\begin{array}{l}\text { Carey, Crystal Ice Caves, Blackfoot, St. } \\
\text { Anthony }\end{array}$ & $\begin{array}{l}\text { Butte City, Monteview, Atomic City, FAA } \\
\text { Tower, Howe, Mud Lake (2), Reno Ranch }\end{array}$ & None \\
\hline TLDs & & $\therefore$ & $\rightarrow$ & 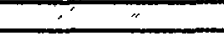 \\
\hline Gamma Radiation & semiannual & $\begin{array}{l}\text { Aberdeen, Blackfoot, Craters of the } \\
\text { Moon, Idaho Falls, Minidoka, Rexburg, } \\
\text { Roberts }\end{array}$ & $\begin{array}{l}\text { Arco, Atomic City, Howe, Monteview, } \\
\text { Mud Lake, Reno Ranch }\end{array}$ & None \\
\hline
\end{tabular}




\begin{tabular}{|c|c|c|c|c|}
\hline \multicolumn{5}{|c|}{$\begin{array}{c}\text { Table A-2 } \\
\text { Approximate Minimum Detectable Concentrations for Radiological Analyses }\end{array}$} \\
\hline Sample Type & Analysis & $\begin{array}{c}\text { Approximate Minimum } \\
\begin{array}{c}\text { Detectable } \\
\text { Concentration }\end{array} \\
\text { (MDC) }\end{array}$ & 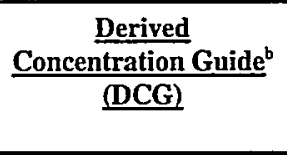 & $\begin{array}{l}\text { Drinking Water } \\
\text { Detection Limits }^{c}\end{array}$ \\
\hline \multirow[t]{7}{*}{ Air (particulate filter) ${ }^{\triangleleft}$} & Gross alpha & $1 \times 10^{-15} \mu \mathrm{Ci} / \mathrm{ml}$ & $2 \times 10^{-14} \mu \mathrm{Ci} / \mathrm{ml}$ & -- \\
\hline & $\dot{\text { Gross beta }}$ & $3 \times 10^{-15} \mu \mathrm{Ci} / \mathrm{ml}$ & $3 \times 10^{-12} \mu \mathrm{Ci} / \mathrm{ml}$ & -- \\
\hline & $\begin{array}{l}\text { Specific gamma } \\
\left({ }^{137} \mathrm{Cs}\right)\end{array}$ & $3 \times 10^{-16} \mu \mathrm{Ci} / \mathrm{ml}$ & $4 \times 10^{-10} \mu \mathrm{Ci} / \mathrm{ml}$ & -- \\
\hline & ${ }^{238} \mathrm{Pu}$ & $2 \times 10^{-18} \mu \mathrm{Ci} / \mathrm{ml}$ & $3 \times 10^{-14} \mu \mathrm{Ci} / \mathrm{ml}$ & -- \\
\hline & ${ }^{239240} \mathrm{Pu}$ & $3 \times 10^{-18} \mu \mathrm{Ci} / \mathrm{ml}$ & $2 \times 10^{-14} \mu \mathrm{Ci} / \mathrm{ml}$ & - \\
\hline & ${ }^{241} \mathrm{Am}$ & $2 \times 10^{-18} \mu \mathrm{Ci} / \mathrm{ml}$ & $2 \times 10^{-14} \mu \mathrm{Ci} / \mathrm{ml}$ & - \\
\hline & ${ }^{91} \mathrm{Sr}$ & $3 \times 10^{-17} \mu \mathrm{Ci} / \mathrm{ml}$ & $9 \times 10^{-12} \mu \mathrm{Ci} / \mathrm{ml}$ & - \\
\hline Air (charcoal cartridge) ${ }^{d}$ & ${ }^{131} \mathrm{I}$ & $4 \times 10^{-15} \mu \mathrm{Ci} / \mathrm{ml}$ & $4 \times 10^{-10} \mu \mathrm{Ci} / \mathrm{ml}$ & - \\
\hline Air (atmospheric moisture)" & ${ }^{3} \mathrm{H}$ & $4 \times 10^{-12} \mu \mathrm{Ci} / \mathrm{ml}$ & $1 \times 10^{-7} \mu \mathrm{Ci} / \mathrm{ml}$ & - \\
\hline Air (precipitation) & ${ }^{3} \mathrm{H}$ & $1 \times 10^{-7} \mu \mathrm{Ci} / \mathrm{ml}$ & $2 \times 10^{-3} \mu \mathrm{Ci} / \mathrm{ml}$ & - \\
\hline \multirow[t]{3}{*}{ Water (drinking \& surface) } & Gross alpha & $3 \mathrm{pCi} / 1$ & $30 \mathrm{pCi} / 1$ & $3 \mathrm{pCi} / \mathrm{l}$ \\
\hline & Gross beta & $2 \mathrm{pCi} / 1$ & $100 \mathrm{pCi} / \mathrm{I}$ & $4 \mathrm{pCi} / \mathrm{l}$ \\
\hline & ${ }^{3} \mathrm{H}$ & $100 \mathrm{pCi} / 1$ & $2 \times 10^{6} \mathrm{pCi} / 1$ & $1000 \mathrm{pCi} / 1$ \\
\hline Milk & ${ }^{131} I$ & $3 \times 10^{-9} \mu \mathrm{Ci} / \mathrm{ml}$ & - & - \\
\hline \multirow[t]{2}{*}{ Wheat } & $\begin{array}{l}\text { Specific gamma } \\
\left({ }^{137} \mathrm{Cs}\right)\end{array}$ & $4 \times 10^{.9} \mu \mathrm{Ci} / \mathrm{g}$ & - & - \\
\hline & ${ }^{91} \mathrm{Sr}$ & $5 \times 10^{-4} \mu \mathrm{Ci} / \mathrm{g}$ & - & -- \\
\hline \multirow[t]{2}{*}{ Lettuce } & $\begin{array}{l}\text { Specific gamma } \\
\left({ }^{137} \mathrm{Cs}\right)\end{array}$ & $1 \times 10^{-7} \mu \mathrm{Ci} / \mathrm{g}$ & - & - \\
\hline & ${ }^{* 1} \mathrm{Sr}$ & $2 \times 10^{-7} \mu \mathrm{Ci} / \mathrm{g}$ & - & -- \\
\hline \multicolumn{5}{|c|}{$\begin{array}{l}\text { a. The MDC is an estimate of the concentration of radioactivity in a given sample type that can be identified with a } 95 \% \text { level of confidence } \\
\text { and a precision of plus or minus } 100 \% \text { under a specified set of typical laboratory measurement conditions. } \\
\text { b. DCGs, set by the DOE, represent reference values for radiation exposure. They correspond to concentrations which would result in a } \\
\text { radiation dose of } 100 \text { mrem/yr through a particular exposure mode such as direct exposure, inhalation, or ingestion of water. } \\
\text { c. These limits are required by the National Primary Drinking Water Regulations ( } 40 \mathrm{CFR} 141 \text { ). The "detection limit" is the terminology } \\
\text { used by the EPA and means the same as the MDC defined above. } \\
\text { d. The approximate MDC is based on an average filtered air volume (pressure corrected) of } 570 \mathrm{~m}^{3} / \mathrm{week} \text {. } \\
\text { e. The approximate MDC is expressed for tritium (as tritiated water) in air, and is based on an average filtered air volume of } 25 \mathrm{~m}^{3} \text {, } \\
\text { assuming an average sampling period of eight weeks. }\end{array}$} \\
\hline
\end{tabular}




\section{Appendix B \\ Helpful Information for Reader}

\section{Radionuclide Nomenclature}

Radionuclides are sometimes expressed with the one- or two-letter chemical symbol for the element. A radionuclide is an unstable, or radioactive, form of an element. A given element may have many different radionuclides. Each is designated by a superscript number to the left of the chemical symbol. This number is the atomic weight of the radionuclide, equal to the number of protons and neutrons in its nucleus. Radionuclides which may be used in this report are shown in the following table:

\begin{tabular}{ll} 
Symbol & Radionuclide \\
\hline${ }^{3} \mathrm{H}$ & Tritium \\
${ }^{7} \mathrm{Be}$ & Beryllium-7 \\
${ }^{51} \mathrm{Cr}$ & Chromium-51 \\
${ }^{54} \mathrm{Mn}$ & Manganese-54 \\
${ }^{58} \mathrm{Co}$ & Cobalt-58 \\
${ }^{60} \mathrm{Co}$ & Cobalt-60 \\
${ }^{65} \mathrm{Zn}$ & Zinc-65 \\
${ }^{90} \mathrm{Sr}$ & Strontium-90 \\
${ }^{95} \mathrm{Nb}$ & Niobium-95
\end{tabular}

$\begin{array}{ll}\text { Symbol } & \text { Radionuclide } \\ { }^{131} \mathrm{I} & \text { Iodine-131 } \\ { }^{134} \mathrm{Cs} & \text { Cesium-134 } \\ { }^{137} \mathrm{Cs} & \text { Cesium-137 } \\ { }^{144} \mathrm{Ce} & \text { Cerium-144 } \\ { }^{181} \mathrm{Hf} & \text { Hafnium-181 } \\ { }^{238} \mathrm{Pu} & \text { Plutonium-238 } \\ { }^{239} 240 \mathrm{Pu} & \text { Plutonium-239/240 } \\ { }^{241} \mathrm{Am} & \text { Americium-241 }\end{array}$

\section{Scientific Notation}

Scientific notation is used to express numbers which are very small and very large. A very small number will be expressed with a negative exponent, e.g., $1.3 \times 10^{-6}$. To convert this number to the more commonly used form, the decimal point must be moved left by the number of places equal to the exponent (in this case, six). The number thus becomes 0.0000013 .

For large numbers, those with a positive exponent, the decimal point is moved to the right by the number of places equal to the exponent. The number $1,000,000$ (or one million) can be written as $1 \times 10^{6}$.

\section{Unit Prefixes}

Units for very small and very large numbers are commonly expressed with a prefix. One example is the prefix kilo, abbreviated $\mathrm{k}$, which means 1,000 of a given unit. A kilometer is therefore equal to 1,000 meters. Prefixes that may be used in this report are:

Prefix
milli
micro
pico

Abbreviation
$\mathrm{m}$
$\mu$
$\mathrm{p}$

$$
\begin{gathered}
\text { Meaning } \\
1 / 1,000\left(=1 \times 10^{-3}\right) \\
1 / 1,000,000\left(=1 \times 10^{-6}\right) \\
1 / 1,000,000,000,000 \\
\left(=1 \times 10^{-12}\right)
\end{gathered}
$$
English Translation one-thousandth one-millionth one-trillionth

\section{Units of Radioactivity and Radiation Exposure and Dose}

The basic unit of radioactivity used in this report is the curie, abbreviated $\mathrm{Ci}$. The curie is defined as the amount of radioactivity equivalent to 37 billion nuclear transformations per second. Historically, this was based upon the radioactivity from one gram of the radionuclide radium- 226 . For 
any other radionuclide, one curie is the amount of that radionuclide that decays at this same rate.

Radiation exposure is expressed in terms of the Roentgen $(\mathrm{R})$, the amount of ionization produced by gamma radiation in air. Dose is given in units of "Roentgen equivalent man," or "rem," which takes into account the effect of radiation on tissues. For the types of environmental radiation generally encountered, the unit of Roentgen is approximately numerically equal to the unit of rem.

\section{Units of Environmental Concentrations}

Concentration of radioactivity in air and milk samples are expressed in units of microcuries per milliliter $(\mu \mathrm{Ci} / \mathrm{ml})$. Concentrations in water samples are expressed as picocuries per liter $(\mathrm{pCi} / \mathrm{l})$. Federal standards are expressed in these units. Radioactivity in foodstuffs are given in microcuries per gram $(\mu \mathrm{Ci} / \mathrm{g})$, dry weight. Radioactivity in soil samples is expressed as picocuries per gram $(\mathrm{pCi} / \mathrm{g})$, dry weight. Annual human radiation exposure, measured by environmental dosimeters, is expressed in units of milliRoentgens (mR). This is sometimes expressed in terms of dose as millirem (mrem).

\section{Uncertainty of Measurements}

Due to many variables, there is always an uncertainty associated with the measurement of environmental contaminants. For radioactivity, the predominant source of uncertainty is due to the inherent statistical nature of radioactive decay events, particularly at the low activity levels encountered in environmental samples. The uncertainty of a measurement is denoted by following the result with a " \pm " (uncertainty) term. This report follows convention in reporting the uncertainty as a $95 \%$ confidence limit (or interval), designated in the tables as " $\pm 2 \mathrm{~s}$." That means there is approximately a $95 \%$ level of confidence that the real concentration in the sample lies somewhere between the measured (reported) concentration minus the uncertainty term and the measured (reported) concentration plus the uncertainty term.

\section{Negative Numbers as Results}

Environmental measurements are frequently conducted at levels where the contaminant, such as radioactivity, cannot be distinguished from natural background levels. In this case, the result will still be reported by the analytical laboratory, even though it is below the measurement system's approximate minimum detectable concentration, or is less than zero. Negative values occur when the measured result is less than a pre-established average background level for the particular system and procedure used. These values, rather than "not detectable" or "zero," are reported to better enable statistical analyses and to observe trends in the data.

\section{Gross versus Specific Analyses}

Many of the radiological analyses of environmental samples yield information only about the overall, or gross, amount of a particular type of radiation (e.g., gross beta), rather than identifying and quantifying specific radionuclides. For example, rather than performing an analysis for particular gamma-emitting radionuclides, called gamma spectroscopy, one can do a gross gamma or, more commonly, a gross beta analysis, since gamma-emitting radionuclides also emit beta particles. This type of analysis is an effective screening tool and is much quicker and less costly than specific radionuclide analyses. 


\section{Appendix C \\ Weekly Gross Alpha and Gross Beta Concentrations in Air 3rd Quarter 1999}

Location Collection Date

$\begin{array}{ll}\text { Blackfoot } & 07 / 07 / 99 \\ \text { NOAA } & 07 / 14 / 99 \\ 07 / 21 / 99 \\ 07 / 28 / 99 \\ 08 / 04 / 99 \\ 08 / 11 / 99 \\ 08 / 18 / 99 \\ 08 / 25 / 99 \\ 09 / 01 / 99 \\ 09 / 08 / 99 \\ 09 / 15 / 99 \\ 09 / 22 / 99 \\ 09 / 29 / 99\end{array}$

Craters of

the Moon

07/07/99

07/14/99

$07 / 21 / 99$

07/28/99

08/04/99

08/11/99

$08 / 18 / 99$

$08 / 25 / 99$

09/01/99

09/08/99

$09 / 15 / 99$

$09 / 22 / 99$

09/29/99

Idaho Falls

07/07/99

$07 / 14 / 99$

$07 / 21 / 99$

$07 / 28 / 99$

$08 / 04 / 99$

$08 / 11 / 99$

$08 / 18 / 99$

$08 / 25 / 99$

09/01/99

09/08/99
Gross Alpha Concentration $\pm 2 s$ $\left(\mu \mathrm{Ci} / \mathrm{ml} \times 10^{-15}\right)$

\author{
Gross Beta Concentration $\pm 2 \mathrm{~s}$ \\ $\left(\mu \mathrm{Ci} / \mathrm{ml} \times 10^{-15}\right)$
}

$$
\begin{aligned}
& 2.0 \pm 1.0 \\
& 4.3 \pm 1.4 \\
& 1.8 \pm 1.2 \\
& 1.9 \pm 0.8 \\
& 2.7 \pm 1.1 \\
& 3.3 \pm 1.0 \\
& 3.2 \pm 0.9 \\
& 4.1 \pm 1.0 \\
& 4.0 \pm 1.0 \\
& 1.2 \pm 0.7 \\
& 3.1 \pm 0.9 \\
& 2.4 \pm 1.2 \\
& 2.2 \pm 0.9
\end{aligned}
$$

$1.6 \pm 0.9$

$3.0 \pm 1.1$

$0.4 \pm 1.2$

$0.8 \pm 0.7$

$3.1 \pm 1.2$

$1.6 \pm 0.7$

$1.1 \pm 0.7$

$2.0 \pm 0.7$

$0.8 \pm 0.6$

$1.3 \pm 0.7$

$1.0 \pm 0.6$

$3.4 \pm 1.1$

$1.5 \pm 0.7$

$2.3 \pm 1.2$

$3.4 \pm 1.5$

$0.8 \pm 1.4$

$0.5 \pm 0.7$

$2.0 \pm 1.2$

$2.3 \pm 1.0$

$1.4 \pm 0.8$

$3.0 \pm 1.1$

$2.2 \pm 1.1$

$1.9 \pm 1.1$
$21 \pm 2$

$29 \pm 3$

$28 \pm 2$

$29 \pm 2$

$34 \pm 3$

$27 \pm 2$

$29 \pm 2$

$32 \pm 2$

$28 \pm 2$

$30 \pm 2$

$31 \pm 2$

$37 \pm 3$

$31 \pm 2$

$18 \pm 2$

$30 \pm 2$

$24 \pm 3$

$24 \pm 2$

$33 \pm 3$

$26 \pm 2$

$24 \pm 2$

$25 \pm 2$

$25 \pm 2$

$26 \pm 2$

$23 \pm 2$

$34 \pm 2$

$24 \pm 2$

$21 \pm 2$

$30 \pm 3$

$28 \pm 3$

$28 \pm 3$

$28 \pm 3$

$29 \pm 3$

$26 \pm 2$

$35 \pm 3$

$32 \pm 3$

$33 \pm 3$ 


\section{Appendix C Weekly Gross Alpha and Gross Beta Concentrations in Air 3rd Quarter 1999}

Location Collection Date

\begin{tabular}{|c|c|c|c|}
\hline & $09 / 15 / 99$ & $2.6 \pm 1.1$ & \\
\hline & $09 / 22 / 99$ & $2.4 \pm 1.5$ & \\
\hline & $09 / 29 / 99$ & $3.3 \pm 1.2$ & \\
\hline Rexburg & $07 / 07 / 99$ & $2.5 \pm 1.1$ & \\
\hline & $07 / 14 / 99$ & $2.8 \pm 1.3$ & \\
\hline & $07 / 21 / 99$ & $1.6 \pm 1.2$ & \\
\hline & $07 / 28 / 99$ & $1.7 \pm 0.7$ & \\
\hline & $08 / 04 / 99$ & $0.3 \pm 0.7$ & \\
\hline & $08 / 11 / 99$ & $2.4 \pm 0.8$ & \\
\hline & $08 / 18 / 99$ & $1.7 \pm 0.7$ & \\
\hline & $08 / 25 / 99$ & $2.7 \pm 0.8$ & \\
\hline & $09 / 01 / 99$ & $2.3 \pm 0.8$ & \\
\hline & $09 / 08 / 99$ & $1.8 \pm 0.8$ & \\
\hline & $09 / 15 / 99$ & $2.7 \pm 0.8$ & \\
\hline - & $09 / 22 / 99$ & $2.8 \pm 1.1$ & \\
\hline & $09 / 29 / 99$ & $1.8 \pm 0.8$ & \\
\hline Mountain View & $07 / 07 / 99$ & $1.7 \pm 0.8$ & $(2.1 \pm 1.1)$ \\
\hline Middle School & $07 / 14 / 99$ & $3.1 \pm 1.1$ & $(4.0 \pm 1.5)$ \\
\hline (replicate) & $07 / 21 / 99$ & $1.8 \pm 1.0$ & $(0.9 \pm 1.1)$ \\
\hline & $07 / 28 / 99$ & $1.8 \pm 0.7$ & $(1.9 \pm 0.9)$ \\
\hline & 08/04/99 & $3.0 \pm 0.9$ & $(1.5 \pm 1.0)$ \\
\hline & $08 / 11 / 99$ & $2.2 \pm 0.7$ & $(2.1 \pm 0.9)$ \\
\hline & $08 / 18 / 99$ & $2.0 \pm 0.7$ & $(1.8 \pm 0.8)$ \\
\hline & $08 / 25 / 99$ & $1.9 \pm 0.7$ & $(2.6 \pm 0.9)$ \\
\hline & $09 / 01 / 99$ & $3.1 \pm 0.8$ & $(2.6 \pm 1.0)$ \\
\hline & $09 / 08 / 99$ & $1.4 \pm 0.7$ & $(2.0 \pm 0.9)$ \\
\hline & $09 / 15 / 99$ & $2.3 \pm 0.7$ & $(1.8 \pm 0.8)$ \\
\hline & $09 / 22 / 99$ & $2.9 \pm 1.1$ & $(2.6 \pm 1.3)$ \\
\hline & 09/29/99 & $1.6 \pm 0.7$ & $(2.4 \pm 1.0)$ \\
\hline Arco & $07 / 07 / 99$ & $1.9 \pm 1.0$ & \\
\hline & $07 / 14 / 99$ & $2.7 \pm 1.2$ & \\
\hline & $07 / 21 / 99$ & $2.1 \pm 1.2$ & \\
\hline & $07 / 28 / 99$ & $1.9 \pm 0.8$ & \\
\hline & $08 / 04 / 99$ & $1.2 \pm 0.8$ & \\
\hline & $08 / 11 / 99$ & $1.5 \pm 0.7$ & \\
\hline
\end{tabular}

\author{
Gross Alpha Concentration $\pm 2 s$ \\ $\left(\mu \mathrm{Ci} / \mathrm{ml} \times 10^{-15}\right)$
}

\author{
Gross Beta Concentration $\pm 2 s$ \\ $\left(\mu \mathrm{Ci} / \mathrm{ml} \times 1^{-15}\right)$
}

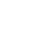

$33 \pm 3$
$41 \pm 3$
$33 \pm 3$

$20 \pm 2$

$29 \pm 3$

$25 \pm 2$

$25 \pm 2$

$0 \pm 1$

$29 \pm 2$

$26 \pm 2$

$27 \pm 2$

$27 \pm 2$

$30 \pm 2$

$26 \pm 2$

$34 \pm 2$

$24 \pm 2$
$20 \pm 2 \quad(21 \pm 2)$
$29 \pm 2 \quad(31 \pm 3)$
$23 \pm 2 \quad(26 \pm 2)$
$24 \pm 2 \quad(28 \pm 3)$
$27 \pm 2 \quad(25 \pm 3)$
$26 \pm 2 \quad(30 \pm 2)$
$23 \pm 2 \quad(26 \pm 2)$
$27 \pm 2 \quad(29 \pm 2)$
$24 \pm 2 \quad(27 \pm 2)$
$27 \pm 2 \quad(31 \pm 2)$
$26 \pm 2 \quad(27 \pm 2)$
$36 \pm 2 \quad(34 \pm 3)$
$29 \pm 2 \quad(26 \pm 2)$

$20 \pm 2$

$29 \pm 3$

$25 \pm 2$

$27 \pm 2$

$19 \pm 2$

$23 \pm 2$ 


\section{Appendix C \\ Weekly Gross Alpha and Gross Beta Concentrations in Air 3rd Quarter 1999}

Location Collection Date

$\begin{array}{ll}08 / 18 / 99 & 2.3 \pm 0.8 \\ 08 / 25 / 99 & 2.3 \pm 0.8 \\ 09 / 01 / 99 & 1.5 \pm 0.8 \\ 09 / 08 / 99 & 1.1 \pm 0.7 \\ 09 / 15 / 99 & 2.3 \pm 0.8 \\ 09 / 22 / 99 & 3.3 \pm 1.2 \\ 09 / 29 / 99 & 1.0 \pm 0.7\end{array}$

$\begin{array}{ll}\text { Atomic City } & 07 / 07 / 99 \\ \text { (replicate) } & 07 / 14 / 99 \\ 07 / 21 / 99 \\ 07 / 28 / 99 \\ 08 / 04 / 99 \\ 08 / 11 / 99 \\ 08 / 18 / 99 \\ 08 / 25 / 99 \\ 09 / 01 / 99 \\ 09 / 08 / 99 \\ 09 / 15 / 99 \\ 09 / 22 / 99 \\ 09 / 29 / 99\end{array}$

Howe

07/07/99

$07 / 14 / 99$

$07 / 21 / 99$

$07 / 28 / 99$

$08 / 04 / 99$

$08 / 11 / 99$

$08 / 18 / 99$

$08 / 25 / 99$

$09 / 01 / 99$

$09 / 08 / 99$

$09 / 15 / 99$

$09 / 22 / 99$

09/29/99

FAA

Tower

07/07/99

07/14/99

$1.3 \pm 0.9$

$3.6 \pm 1.1$

$1.4 \pm 0.8$
$1.0 \pm 1.1$

$1.4 \pm 1.0$
Gross Alpha Concentration $\pm 2 s$ $\left(\mu \mathrm{Ci} / \mathrm{ml} \times 10^{-15}\right)$
Gross Beta Concentration $\pm 2 \mathrm{~s}$ $\left(\mu \mathrm{Ci} / \mathrm{ml} \times 10^{-15}\right)$
$24 \pm 2$
$28 \pm 2$
$26 \pm 2$
$26 \pm 2$
$26 \pm 2$
$36 \pm 3$
$27 \pm 2$

$(1.2 \pm 0.9)$

$(2.4 \pm 1.1)$

$(2.4 \pm 1.3)$

$(2.4 \pm 0.9)$

$(2.9 \pm 1.4)$

$(1.5 \pm 0.9)$

$(1.2 \pm 0.9)$

$(1.7 \pm 0.8)$

$(1.8 \pm 1.0)$

$(1.3 \pm 0.9)$

$(1.3 \pm 0.9)$

(3.0 \pm 1.3$)$

(no sample)

$20 \pm 2$

$25 \pm 2$

$(22 \pm 2)$

$(30 \pm 2)$

$(29 \pm 3)$

$25 \pm 2$

$(25 \pm 2)$

$35 \pm 3$

$(34 \pm 3)$

$24 \pm 2$

$(27 \pm 3)$

$23 \pm 2$

(27 \pm 3 )

$25 \pm 2$

$(29 \pm 3)$

$27 \pm 2$

$(29 \pm 3)$

$26 \pm 2$

$(31 \pm 2)$

$25 \pm 2$

$33 \pm 2$

$(28 \pm 2)$

$26 \pm 2$

(37 \pm 3 )

(no sample)

$22 \pm 2$

$28 \pm 3$

$27 \pm 2$

$33 \pm 3$

$46 \pm 4$

$26 \pm 3$

$28 \pm 2$

$29 \pm 4$

$30 \pm 3$

$31 \pm 3$

$28 \pm 2$

$36 \pm 8$

$28 \pm 2$

$19 \pm 2$

$23 \pm 2$ 


\section{Appendix C \\ Weekly Gross Alpha and Gross Beta Concentrations in Air 3rd Quarter 1999}

Location Collection Date

\begin{tabular}{|c|c|c|}
\hline & $07 / 21 / 99$ & $0.5 \pm 1.0$ \\
\hline & $07 / 28 / 99$ & $1.2 \pm 0.9$ \\
\hline & $08 / 04 / 99$ & $3.0 \pm 1.3$ \\
\hline & $08 / 11 / 99$ & $2.1 \pm 0.9$ \\
\hline & 08/18/99 & $2.0 \pm 0.9$ \\
\hline & $08 / 25 / 99$ & $2.5 \pm 0.9$ \\
\hline & $09 / 01 / 99$ & $1.3 \pm 0.8$ \\
\hline & $09 / 08 / 99$ & $1.1 \pm 0.9$ \\
\hline & $09 / 15 / 99$ & $2.5 \pm 0.9$ \\
\hline & $09 / 22 / 99$ & $2.4 \pm 1.2$ \\
\hline & $09 / 29 / 99$ & $1.8 \pm 1.0$ \\
\hline Monteview & $07 / 07 / 99$ & $2.4 \pm 1.1$ \\
\hline & $07 / 14 / 99$ & $2.7 \pm 1.2$ \\
\hline & $07 / 21 / 99$ & $0.9 \pm 1.1$ \\
\hline & $07 / 28 / 99$ & $2.0 \pm 0.9$ \\
\hline & $08 / 04 / 99$ & $2.4 \pm 1.2$ \\
\hline & $08 / 11 / 99$ & $2.8 \pm 1.0$ \\
\hline & $08 / 18 / 99$ & $2.9 \pm 1.0$ \\
\hline & $08 / 25 / 99$ & $2.5 \pm 0.8$ \\
\hline & $09 / 01 / 99$ & $2.5 \pm 0.9$ \\
\hline & 09/08/99 & $0.8 \pm 0.7$ \\
\hline & $09 / 15 / 99$ & $1.5 \pm 0.8$ \\
\hline & $09 / 22 / 99$ & $3.2 \pm 1.2$ \\
\hline & $09 / 29 / 99$ & $3.0 \pm 0.9$ \\
\hline Mud & $07 / 07 / 99$ & $1.3 \pm 0.8$ \\
\hline Lake & $07 / 14 / 99$ & $2.6 \pm 1.0$ \\
\hline & $07 / 21 / 99$ & $1.8 \pm 1.1$ \\
\hline & $07 / 28 / 99$ & $2.1 \pm 0.7$ \\
\hline & 08/04/99 & $1.8 \pm 0.9$ \\
\hline & $08 / 11 / 99$ & $3.4 \pm 0.9$ \\
\hline & $08 / 18 / 99$ & $2.5 \pm 0.9$ \\
\hline & $08 / 25 / 99$ & $3.6 \pm 0.9$ \\
\hline & $09 / 01 / 99$ & $2.8 \pm 0.9$ \\
\hline & $09 / 08 / 99$ & $1.7 \pm 0.7$ \\
\hline & $09 / 15 / 99$ & $2.6 \pm 0.8$ \\
\hline & $09 / 22 / 99$ & $3.0 \pm 1.0$ \\
\hline
\end{tabular}

\section{Gross Beta Concentration $\pm 2 \mathrm{~s}$} $\left(\mu \mathrm{Ci} / \mathrm{ml} \times 10^{-15}\right)$
$24 \pm 2$

$22 \pm 3$

$44 \pm 3$

$22 \pm 2$

$25 \pm 2$

$25 \pm 2$

$28 \pm 2$

$26 \pm 2$

$27 \pm 2$

$36 \pm 3$

$26 \pm 2$

$21 \pm 2$

$32 \pm 3$

$29 \pm 2$

$29 \pm 3$

$24 \pm 3$

$26 \pm 2$

$26 \pm 2$

$30 \pm 2$

$30 \pm 2$

$30 \pm 2$

$26 \pm 2$

$37 \pm 3$

$28 \pm 2$

$21 \pm 2$

$31 \pm 2$

$26 \pm 2$

$26 \pm 2$

$22 \pm 2$

$28 \pm 2$

$25 \pm 2$

$30 \pm 2$

$29 \pm 2$

$27 \pm 2$

$27 \pm 2$

$34 \pm 2$ 


\section{Appendix C \\ Weekly Gross Alpha and Gross Beta Concentrations in Air 3rd Quarter 1999}

Location Collection Date

Gross Alpha Concentration $\pm 2 \mathrm{~s}$ $\left(\mu \mathrm{Ci} / \mathrm{ml} \times 10^{-15}\right)$
Gross Beta Concentration $\pm 2 s$ $\left(\mu \mathrm{Ci} / \mathrm{ml} \times 10^{-15}\right)$
09/29/99

Reno

Ranch

INEEL

Main

Gate

EFS

07/07/99

07/14/99

07/21/99

07/28/99

08/04/99

08/11/99

$08 / 18 / 99$

08/25/99

$$
1.8 \pm 0.8
$$

$1.5 \pm 1.1$

$2.6 \pm 1.4$

$-0.7 \pm 1.8$

$0.5 \pm 1.0$

$1.9 \pm 1.0$

$2.4 \pm 0.9$

$1.7 \pm 0.7$

$2.4 \pm 0.8$

$3.0 \pm 0.9$

$0.8 \pm 0.6$

$1.9 \pm 0.8$

$2.2 \pm 1.0$

$1.3 \pm 0.7$

$1.2 \pm 0.8$

$2.1 \pm 1.0$

$2.7 \pm 1.3$

$1.8 \pm 0.8$

$2.1 \pm 1.1$

$1.5 \pm 0.8$

$1.8 \pm 0.8$

$1.7 \pm 0.8$

$2.1 \pm 0.9$

$0.6 \pm 0.8$

$2.0 \pm 0.9$

$2.5 \pm 1.1$

$1.6 \pm 0.8$

$1.6 \pm 1.0$

$2.5 \pm 1.3$

$1.4 \pm 1.2$

$1.8 \pm 0.9$

$1.9 \pm 1.2$

$2.4 \pm 1.0$

$2.3 \pm 1.0$

$2.4 \pm 0.9$
$27 \pm 2$

$22 \pm 2$

$32 \pm 3$

$23 \pm 4$

$38 \pm 4$

$27 \pm 2$

$27 \pm 2$

$26 \pm 2$

$30 \pm 2$

$28 \pm 2$

$28 \pm 2$

$23 \pm 2$

$31 \pm 2$

$23 \pm 2$

$21 \pm 2$

$29 \pm 2$

$25 \pm 2$

$25 \pm 2$

$24 \pm 2$

$25 \pm 2$

$24 \pm 2$

$26 \pm 2$

$25 \pm 2$

$28 \pm 2$

$25 \pm 2$

$33 \pm 2$

$24 \pm 2$

$22 \pm 2$

$33 \pm 3$

$27 \pm 2$

$29 \pm 3$

$25 \pm 3$

$26 \pm 2$

$28 \pm 2$

$29 \pm 3$ 


\section{Appendix C \\ Weekly Gross Alpha and Gross Beta Concentrations in Air 3rd Quarter 1999}

Location Collection Date

$\begin{array}{ll}09 / 01 / 99 \\ 09 / 08 / 99 \\ 09 / 15 / 99 \\ 09 / 22 / 99 \\ 09 / 29 / 99 \\ \text { Van Buren } & 07 / 07 / 99 \\ \text { Avenue } & 07 / 14 / 99 \\ & 07 / 21 / 99 \\ & 07 / 28 / 99 \\ & 08 / 04 / 99 \\ & 08 / 11 / 99 \\ 08 / 18 / 99 \\ 08 / 25 / 99 \\ 09 / 01 / 99 \\ 09 / 08 / 99 \\ 09 / 15 / 99 \\ 09 / 22 / 99 \\ 09 / 29 / 99\end{array}$

Gross Alpha Concentration $\pm 2 s$ $\left(\mu \mathrm{Ci} / \mathrm{ml} \times 10^{-15}\right)$
Gross Beta Concentration $\pm 2 s$ $\left(\mu \mathrm{Ci} / \mathrm{ml} \times 10^{-15}\right)$
$1.3 \pm 0.9$
$1.4 \pm 0.9$
$1.1 \pm 0.8$
$2.4 \pm 1.4$
$0.8 \pm 0.8$

$2.2 \pm 1.1$

$3.3 \pm 1.2$

$2.9 \pm 1.6$

$1.7 \pm 0.9$

$2.0 \pm 1.2$

$1.2 \pm 0.9$

$1.6 \pm 0.9$

$2.5 \pm 0.9$

$1.8 \pm 0.9$

$2.0 \pm 1.0$

$2.3 \pm 1.0$

$2.5 \pm 1.5$

$1.9 \pm 1.0$
$28 \pm 2$

$30 \pm 2$

$29 \pm 2$

$35 \pm 3$

$28 \pm 2$

$19 \pm 2$

$30 \pm 3$

$29 \pm 3$

$27 \pm 3$

$33 \pm 3$

$27 \pm 3$

$26 \pm 3$

$31 \pm 3$

$28 \pm 2$

$30 \pm 3$

$28 \pm 2$

$32 \pm 3$

$29 \pm 3$ 